(2) Open Access Full Text Article

RESPONSE TO LETTER

\title{
Poor outcome of laparoscopic cholecystectomy in patients with COPD: how determinant it is? [Response to Letter]
}

This article was published in the following Dove Press journal:

International Journal of Chronic Obstructive Pulmonary Disease

\section{Kuang-Ming Liao' \\ Chung-Han $\mathrm{Ho}^{2}$}

'Department of Internal Medicine, Chi Mei Medical Center, Chiali, Tainan City, Taiwan; ${ }^{2}$ Department of Medical Research, Chi Mei Medical Center, Chiali, Tainan City, Taiwan
Correspondence: Chung-Han Ho Department of Surgery, Chi Mei Medical Center, No 90I, Zhonghua Road, Yongkang District, Tainan 710, Taiwan Tel +886628I 28II ext 52653

Email ho.c.hank@gmail.com

\section{Dear editor}

We thank the authors for their comments. In our Table 3, the odds ratio of adverse clinical outcomes for laparoscopic cholecystectomy patients with and without COPD was adjusted by all variables listed in Table 1, including age at surgery, gender, income, hospital level, and comorbidities.

We agreed that time period was long in our observation study and the management strategy, especially for COPD patients, has evolved and changed a lot. It is an inherent limitation in the long observational study.

Secondly, the information on intraoperative and postoperative respiratory management cannot be obtained from the database. The preoperative optimization strategy for risk reduction and postoperative patients care were relevant to individual physician performance. This is not only the characteristics of the national database but also real-world conditions.

In Taiwan, if hospitals are capable of performing laparoscopy, most of them also provide services of hemodialysis, mechanical ventilation, and intensive care unit.

We agreed that proper patient selection is crucial and is associated with outcome and prognosis.

\section{Disclosure}

The authors report no conflicts of interest in this communication. 
Dove Medical Press encourages responsible, free and frank academic debate. The content of the International Journal of Chronic Obstructive Pulmonary Disease 'letters to the editor' section does not necessarily represent the views of Dove Medical Press, its officers, agents, employees, related entities or the International Journal of Chronic Obstructive Pulmonary Disease editors. While all reasonable steps have been taken to confirm the content of each letter, Dove Medical Press accepts no liability in respect of the content of any letter, nor is it responsible for the content and accuracy of any letter to the editor.

International Journal of Chronic Obstructive Pulmonary Disease

\section{Publish your work in this journal}

The International Journal of COPD is an international, peer-reviewed journal of therapeutics and pharmacology focusing on concise rapid reporting of clinical studies and reviews in COPD. Special focus is given to the pathophysiological processes underlying the disease, intervention programs, patient focused education, and self management protocols. This journal is indexed on PubMed Central, MedLine and CAS. The manuscript management system is completely online and includes a very quick and fair peer-review system, which is all easy to use. Visit http://www.dovepress.com/testimonials.php to read real quotes from published authors. 